\title{
The Dangerous Illusion of International Financial Standards and the Legacy of the Financial Stability Forum
}

\author{
CALLY JORDAN*
}

\begin{abstract}
In the aftermath of the Asian Financial Crisis, and the criticism directed towards the International Monetary Fund, in particular, for not having seen it coming, the Financial Stability Forum (FSF) was created in 1999 under a mandate from the G7 ministers of finance and central bank governors. The Asian Financial Crisis arose suddenly, spread rapidly, and spared neither developed nor developing economies in the region, although some fared much better than others. In retrospect, the causes of the crisis were obvious and the consequences predictable. "Contagion" entered the financial lexicon.

Thus, the role of the FSF was to promote financial stability across national borders and provide an early warning system, identifying potential weaknesses or "vulnerabilities" in national financial systems, with a view to preventing a repetition of the localized financial chaos of 1997. The development of international standards for financial and other commercial regulation and the implementation of the Financial Sector Assessment Program or "FSAP"-designed to monitor and assess financial stability on a country by country basis-were two of the initiatives associated with the FSF.
\end{abstract}

* Visiting Professor, Duke Law School; Associate Professor, Melbourne Law School; European Corporate Governance Institute. 
The Asian Financial Crisis, however, was just a tremor compared to the earthquake of the current Global Financial Crisis (GFC) which has shaken financial markets around the world less than a decade after the establishment of the FSF.

That the FSF was a failure is patently obvious. It has been relegated to the dustbin of history with little ado. This paper will endeavour to identify some of the reasons for the failure of the FSF, with a particular focus on international standard setting and financial sector assessment initiatives, with a view to assessing the prospects of the reincarnation of the FSF, the new Financial Stability Board (FSB).

\section{TABLE OF CONTENTS}

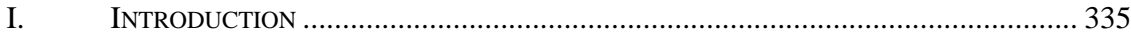

II. The Crisis: Some Proximate CAUSES AND A LitTLE TheORY …....................... 336

A. Immediate Culprits in the Global Financial Crisis ................................... 337

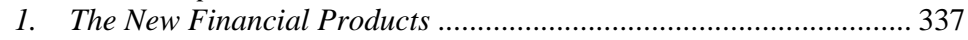

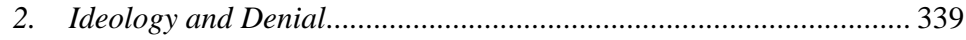

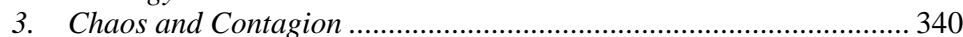

4. False Cognates and False Friends .............................................. 342

B. Chaos and Path Dependency ................................................................. 343

III. CONTAGION AND PREDICTABILITY ....................................................................... 346

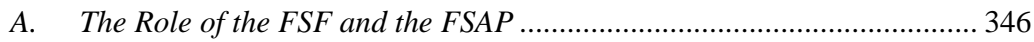

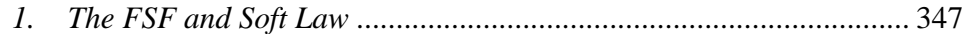

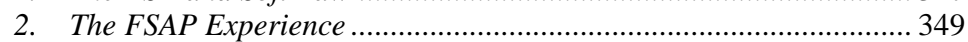

B. Inadequacies of the FSAP Experience .................................................... 350

1. Problems with Execution of the FSAP Exercises ............................. 350

2. Problems with the Substance of the FSAP Exercise............................ 354

IV. CONCLUSION 359 
"The financial system was a victim of its own rationality."

Gunther Teubner, October 31, 2008. ${ }^{1}$

\section{INTRODUCTION}

It was a good idea at the time; a forum to bring together, in a fairly neutral and low-key manner, financial sector representatives, who for reasons of institutional isolation ${ }^{2}$ or otherwise, would not necessarily sit down together on a regular basis. So in 1999, in the aftermath of the Asian Financial Crisis, and the criticism directed towards the International Monetary Fund (IMF) in particular for not having seen it coming, the Financial Stability Forum (FSF) was created under a mandate from the G7 ministers of finance and central bank governors. ${ }^{3}$ After an initial honeymoon period, however, the FSF appeared to lose its way, ultimately proving to be a monumental disappointment.

The Asian Financial Crisis arose suddenly, spread rapidly, and spared neither developed nor developing economies in the region; although some fared much better than others. ${ }^{4}$ In retrospect, the causes of the crisis were obvious and the consequences predictable. "Contagion" entered the financial lexicon.

Thus the role of the FSF was to promote financial stability across national borders and provide an early warning system, identifying potential weaknesses or "vulnerabilities" in national financial systems, with a view to preventing a repetition of the localized financial chaos of 1997. The development of international standards for financial and other commercial regulation and the implementation by the IMF and the World Bank of the Financial Sector Assessment Program (FSAP)—

1. Gunther Teubner, Univ. of Frankfurt Professor of Private Law and Legal Sociology, Two Kinds of Legal Pluralism: Collision of Rules in the Double Fragmentation of World Society, Inaugural Speech Delivered to the Comparative Law, Economics and Finance Program, International University College Torino (It.) (Oct. 31, 2008).

2. Although the International Monetary Fund and the World Bank sit across the street from each other in Washington, D.C., the institutional cultures are very different and their rivalry notorious.

3. See History, FIN. STABILITY BD., http://www.financialstabilityboard.org/about/ history.htm (last visited Mar. 5, 2010). See also Douglas W. Arner \& Michael W. Taylor, The Global Financial Crisis and the Financial Stability Board: Hardening the Soft Law of International Financial Regulation, 32 U. NEW S. WALES L.J. 488, 489 (2009).

4. China and Vietnam, for example, with their then relatively closed economies. 
which is designed to monitor and assess financial stability on a country by country basis - were two of the initiatives associated with the FSF.

The Asian Financial Crisis, however, was just a tremor compared to the earthquake of the global financial crisis of 2008 (GFC), which has shaken financial markets around the world, less than a decade after the establishment of the FSF.

That the FSF was a failure is patently obvious. It has been relegated to the dustbin of history with little ado. This paper will endeavour to identify some of the proximate causes of the GFC in light of popular theories of finance and how the nature of the crisis revealed the inadequacies of both the FSF and the instrumentalities it relied on to fulfill its mandate, international standard setting and financial sector assessment initiatives. The paper concludes with a preliminary assessment of the prospects for the newly constituted Financial Stability Board (FSB) which has replaced the FSF.

\section{The CRIsis: SOME ProXimate CAUSES AND A LitTLE TheORY}

It was everyone's worst nightmare: the spectre of systemic collapse. And this time, everyone was in it together. Financial crises are no strangers to world economies in recent times. But this one was truly different, stunning in its breadth, speed, and dramatic consequences.

Around the world, hundreds of millions of people were affected. Shocked and dismayed, people asked how and why, and the most puzzling questions of all, why here and why now. As a modicum of normality returns to financial markets, a torrent of analysis has started to spew forth. There is agitated finger-pointing and second-guessing; some sacred cows of modern finance, such as the efficient market hypothesis, ${ }^{5}$ have taken a goring but will likely survive. On the other hand, more marginal theories which contribute to the understanding of modern finance, such

5. For the lively debate, see Efficiency and Beyond, ECONOMIST, July 18, 2009, at 68 (noting that "[i]n 1978 Michael Jensen, an American economist, boldly declared that 'there is no other proposition in economics which has more solid empirical evidence supporting it than the efficient- markets-hypothesis (EMH) . . Eugene Fama, of the University of Chicago, defined its essence: that the price of a financial asset reflects all available information that is relevant to its value... On such ideas, and on the complex mathematics that described them, was founded the Wall Street profession of financial engineering. The engineers designed derivatives and securitizations [sic] from simple interest-rate options to ever more intricate credit default swaps and collateralised [sic] debt obligations. All the while, confident in the theoretical underpinnings of their inventions, they reassured any doubters that all this activity was not just making bankers rich. It was making the financial system safer and the economy healthier. That is why many people view the financial crisis that began in 2007 as a devastating blow to the credibility not only of banks but also of the entire academic discipline of financial economics.”). 
as the chaos theory and the path dependency of market institutions, have received resounding validation. ${ }^{6}$

\title{
A. Immediate Culprits in the Global Financial Crisis
}

\section{The New Financial Products}

\section{The complexity of modern finance is one obvious culprit: ${ }^{7}$}

\begin{abstract}
We have reached the point where some financial engineers have managed to baffle even themselves. Along the way, though, they seemed to have befuddled their boards of directors, risk management committees, lawyers, accountants, customers, and regulators. A large financial institution cannot go from booking a position at par one day to writing off $\$ 20$ billion of the value of that position three months later, without admitting a degree of confusion about the investment's true risk profile. ${ }^{8}$
\end{abstract}

Brilliant innovation in financial products metamorphosed into incomprehensible gibberish:

What started out as an I lend-you borrow proposition developed into something like this: 'A Cayman Island special purpose bankruptcy-proof vehicle borrows money from qualified institutional buyers in order to acquire a credit-linked note issued by a Luxembourg entity, guaranteed by a Jersey financing subsidiary of a Cyprus corporation that in turn hedges the risk with a credit default swap written by an Irish entity ...' And so on. ${ }^{9}$

Such gibberish roared through Wall Street, meeting no resistance, regulatory or otherwise. ${ }^{10}$

Centuries old legal principles, such as the notion of "insurable interest,"11 were cast aside. In English law, the concept of insurable interest found

6. See John Authers, Wanted: New Model for Market, Fin. TIMES, Sept. 29, 2009, at 9, available at http://www.ft.com/cms/s/0/cefa0bfa-ac58-11de-a754-00144feabdc0.html (last viewed Aug. 11, 2010).

7. See Lee C. Buchheit, Did We Make Things Too Complicated?, 27 InT’L FIN. L. Rev. 24, 24 (2008). See also Michael Lewis, The End, PorTFOLIO, Nov. 11, 2008, available at http://www.portfolio.com/news-markets/national-news/portfolio/2008/11/11/The-End-ofWall-Streets-Boom.

8. Buchheit, supra note 7, at 25.

9. Id.

10. Buchheit does not spare his fellow lawyers in this critique: "Why do some contracts, tantamount to crimes against humanity, not occasion more expressions of outrage from bankers, analysts, rating agencies, investors and regulators? (They do sometimes incur the wrath of the judiciary). These people often meekly accept a turgid, incestuous, redundant, disorganised and arthritic contract without even a bleat of protest. " Buchheit, supra note 7 , at 26.

11. See English \& Scottish Law Commissions, Insurable Interest 2 (Issues Paper No. 4, Jan. 14, 2008), available at http://www.lawcom.gov.uk/docs/Insurance_Contract_ 
its expression in the Life Assurance Act 1774: "Whereas it hath been found by experience that the making insurances on lives or other events wherein the assured shall have no interest hath introduced a mischievous kind of gaming," ${ }^{12}$ the mischievous kind of gaming being the incentive to murder an insured party.

The issue of whether credit derivatives (the financial product that felled AIG, then the largest insurance company in the world) were "insurance" was one of the questions considered by Law Commission in the United Kingdom in a 2008 Issue Paper on insurable interests. ${ }^{13}$ Although credit derivatives (a category of "toxic asset") plainly came within one of the common law definitions of insurance, ${ }^{14}$ both the U.K. regulator, the Financial Services Authority (FSA), and the industry association, the International Swaps and Derivatives Association (ISDA), argued against their characterization as insurance and, thus, their regulation. ${ }^{15}$ "The FSA doubts there is a strong regulatory interest in the use to which insurance (or any other financial instrument) is put." ${ }^{\prime 16}$ It is hard to imagine these words being uttered by a financial regulator today. It is as though the regulators of some of the world's major financial markets went through a period of mass hysteria, blinded by the brilliance of the markets. In fact, a requirement similar to "insurable interest" has now been proposed for credit derivatives, ${ }^{17}$ in order to defuse the moral hazard associated with their usage.

Equally, old fashioned "gaming laws," which had once served to dampen the worst aspects of rampant speculation, no longer operated as

Law_Issues_Paper_4.pdf (“At its simplest, the doctrine of insurable interest requires that someone taking out insurance gains a benefit from the preservation of the subject matter of the insurance or suffers a disadvantage should it be lost."). This paper, in positing that the issue should have been left to the market, noted that Australia eliminated the requirement for an insurable interest in an insurance contract in 1995 by an amendment to the Insurance Contracts Act 1984 (Cth). See id. app. A, at 71-73. See also M. Todd Henderson, Credit Derivatives Are Not 'Insurance,' 16 ConN. INs. L. J. 1, 11, 17, 32-33 (2009-10).

12. Life Assurance Act 1774, 14 Geo. 3, c. 48 (Eng.), reprinted in English \& Scottish Law Commissions, supra note 11, app. B, at 79.

13. See English \& Scottish Law Commissions, supra note 11, at 47-50.

14. See id. at 48 ("They are contracts whereby one party promises to pay to the other party a sum of money upon the occurrence of a specified event.").

15. See id. at 48-49 ("[A]ny review of the boundary between contracts of insurance and other types of contract risks damaging [market] consensus and undermining confidence in these economically significant products.”).

16. See id. at 47.

17. For example there have been calls for "more skin in the game." One proposal is to require purchasers of credit derivatives to actually hold the underlying bond against which default protection is sought, in effect requiring an "insurable interest." See Reforming Finance-Derivatives-Naked Fear, EconOMIST, Aug. 8, 2009, at 64. 
a brake. ${ }^{18}$ The United Kingdom, for example, repealed the Gaming Act 1845 by enacting the Gambling Act 2005, which came into effect September $1,2007 .^{19}$

The nature of the new financial products though was the key to their consequences in the United States. Unlike financial products of the past, these new inventions linked routine retail banking directly to supercharged capital markets-Main Street to Wall Street. This was not just a housing bubble bursting; it was not just a credit crisis; it was not just a stock market crash. The new hybrid financial products, by linking heretofore loosely correlated markets, became purveyors of systemic risk.

For the most part, the new financial products flew under the radar screen of regulatory oversight, investor reliance being put instead on credit ratings. Structured products, as they were called, were deliberately "structured" to avoid tripping regulatory triggers. Particularly in the United States, this was facilitated by a fragmented and outdated financial regulatory regime which provided a wealth of opportunities for regulatory arbitrage. $^{20}$ Elsewhere, as in the United Kingdom, regulatory authorities were lulled by the siren song of "regulation-lite."

\section{Ideology and Denial}

Exacerbating what might have been a predictable, and ultimately welcome, correction in an overheated housing market in the United States, were foolish and irresponsible lending practices, far down the financial chain. ${ }^{21}$ The manner in which these practices worked their way

18. See Lynn Stout, How Deregulating Derivatives Led to Disaster, and Why ReRegulating Them Can Prevent Another, 1 LOMBARD STREET 4-9 (July 6, 2009), http://www. finreg21.com/files/finreg21-finreg21/Lombard\%207.pdf.

19. Gaming Act, 1845, 8 \& 9 Vict., c. 109 (Eng.); Gambling Act, 2005, c. 19 (Eng.).

20. The Commodity Futures Modernization Act of 2000, 7. U.S.C. §§ 1-25, had essentially exempted OTC derivatives from regulation by either the CFTC or the SEC. In the wake of the global financial crisis, the United States Treasury sent to Congress the Over-the-Counter Derivatives Markets Act of 2009, stating, "the OTC derivative markets will be comprehensively regulated for the first time.” Press Release TG-261, U.S. Dep't of the Treas., Administration's Regulatory Reform Agenda Reaches New Milestone: Final Piece of Legislative Language Delivered to Capital Hill, (Aug. 11, 2009), http://www. treasury.gov/press-center/press-releases/Pages/tg261.aspx.

21. One of the most striking examples given by Michael Lewis is of the nonEnglish speaking Mexican strawberry picker in California's San Fernando Valley. With an annual income of $\$ 14,000$, he was given a mortgage to purchase a $\$ 720,000$ house. See Lewis, supra note 7. 
through the financial system is in part a testimony to the dangers of ideologically driven policymaking and denial in the face of imminent disaster.

Had the U.S. Federal Reserve and the U.S. Treasury moved more quickly, would the crisis have been contained? The Hong Kong Government did not let ideological scruples deter their quick and decisive action in creating the Tracker Fund in the face of the Asian financial crisis a decade before. ${ }^{22}$ That the Hong Kong Government made a tidy profit in the long term was a sweet vindication, given the immediate criticisms their "anti-market" actions attracted, in particular from international financial institutions, such as the IMF.

\section{Chaos and Contagion}

In the United States, the hurricane of financial chaos slammed against a creaking and outdated regulatory infrastructure. At the eye of the storm, was the fragmented financial and banking regulatory regime: dozens of state regulators interacting with an array of different types of financial institutions, grinding against the rocks of the Federal Reserve and the U.S. Treasury. ${ }^{23}$

The hurricane of the financial crisis is no idle metaphor. Chaos theory, which has been applied to financial systems, originated in the study of weather systems. ${ }^{24}$ The so-called "butterfly effect" (does the flapping of

22. "In August 1998, the Hong Kong Government acquired a substantial portfolio of Hong Kong shares during a market operation. The Exchange Fund Investment Limited (EFIL) was established in October 1998 by the Government to advise on the disposal of this portfolio in an orderly manner. When seeking to dispose of these shares, the Government chose a stock neutral solution that would create minimal disruption to the market. An Exchange Traded Fund, the Tracker Fund of Hong Kong (TraHK), which met these requirements and added depth to Hong Kong's capital markets was launched in November 1999 as the first step in the Government's disposal programme. State Street Global Advisors Asia Ltd was appointed as the Fund Manager and State Street Bank and Trust Company was appointed as the Trustee of TraHK. With an issue size of $\$ 33.3$ billion (H.K.) (approximately \$4.3 billion (U.S.)), TraHK’s Initial Public Offering (IPO) was the largest IPO ever in Asia ex-Japan at the time of launch. Since the IPO, approximately \$140.4 billion (H.K.) (by October 15, 2002) in Hang Seng Index constituent stocks has been returned to the market through TraHK's unique tap mechanism.” History of Tracker Fund, TRACKER Fund OF HONG KONG, http://www.trahk.com.hk/eng/homepage.asp (last visited Feb. 20,2010). See also Y.C. Jao, Financial Reform in Hong Kong, in InTERNATIONAL HANDBOOK ON FINANCIAL REFORM 126 (Maximillian J.B.Hall ed., 2003).

23. There are literally hundreds of state insurance, credit, banking and securities regulators in the United States in addition to their federal counterparts. See, e.g., Fed. Citizen Info. Ctr., U.S. Gen. Servs. Admin., Consumer Action HANDBOOK, 14347 (2010), available at http://www.consumeraction.gov/viewpdf.shtml; NASAA Member Representative List, NASAA, available at http://www.nasaa.org/about_nasaa/2062.cfm (last visited Feb. 20, 2010).

24. Edward N. Lorenz, Professor of Meteorology, Predictability: Does the Flap of a Butterfly's Wings in Brazil Set Off a Tornado in Texas?, Speech Delivered at the American 
a butterfly's wings in Brazil set off a tornado in Texas) postulates that a small change in initial conditions in a system causes a chain of events leading to large scale phenomenon. Rather than being random or unpredictable (the title of Lorenz's seminal 1972 study was Predictability, after all), the future dynamics in the system are fully defined by initial conditions. As the noted German legal scholar Gunther Teubner recently observed, the "financial system has been a victim of its own rationality.",25

If there had been any doubt as to the extent of integration of world capital markets forming one "system," this global financial crisis laid it to rest. "Contagion" had spread rapidly during the Asian financial crisis in 1997-1998, but was more or less regionally contained, and, even within the region, had little effect on certain economies. ${ }^{26}$ Not so this time.

Capital markets feed on information. ${ }^{27}$ Information is now transmitted instantaneously, thanks to modern technology. This same technology, of course, permits the virtually instantaneous transmission of capital. When someone cries "fire" and there is a stampede for the door, this same technology fuels the conflagration in the markets, and also makes it possible. $^{28}$

Two other factors acted as accelerants in the case of this particular conflagration: (1) ideology and (2) the propagation of what might, for want of a better term, be called "false cognates" or "false friends." 29 In

Association for the Advancement of Science, 139th Meeting (Dec. 29, 1972). See also Authers, supra note 6.

25. Teubner, supra note 1.

26. Relatively "closed" economies of the time, China and Vietnam, for example.

27. Cf. Efficiency and Beyond, supra note 5.

28. For the current debate on "flash trading," see Stephen Bernard, Meltdown 101: 'Flash orders' on Wall Street, AssociATED PRESS, Aug. 13, 2009 (describing the practice of "certain members of exchanges - often large institutions - buying and selling information about ongoing stock trades milliseconds before that information is made public). High speed computer software can take advantage of that brief period between when an order is placed and when it's executed to all those members to potentially get better prices and profits by slipping in and making the trade themselves. Id. For example, if an exchange that offers flash trading gets an order from someone who wants to sell shares of stock, it can 'flash' that order on its system to find a buyer, before making it available to buyers using other exchanges. Id. Traders pay fees to an exchange to access the information early. Id. Three large exchanges-Nasdaq, BATS and Direct Edge-have offered flash order services. Id. The Nasdaq OMX Group Inc. announced that they will voluntarily cease offering such services September 1, 2009. Associated Press, Nasdaq to Stop Offering Flash Trading September 1, MSNBC (Aug. 6, 2009, 2:29 PM), http://www.msnbc.msn.com/id/32317239.

29. "False cognates are pairs of words in the same or different languages that are similar in form and meaning but have different roots. That is, they appear to be or 
September and October of 2008, the actions of the U.S. Federal Reserve and the U.S. Treasury themselves, the immediate solutions to the crisis, were a main driver of the chaos. That an administration, at that time so ideologically well-defined, engaged in a volte face intervention in financial markets of a kind unparalleled in U.S. history, pushed all the market panic buttons. The message, the information, transmitted to the market was very clear: this must be worse than we thought.

False cognates, or its variant, false friends, as they are known in linguistic studies, present different issues. The problem (read, the crisis) may appear the same in different places, but in fact, its origins are different from one economy to another. Or, as with false friends (words that sound similar, and may in fact be related linguistically, but which have strikingly different meanings from language to language), the problems may appear similar from economy to economy, but in fact their significance varies dramatically from one place to another.

So, as the hue and cry about the U.S. financial crisis spread like electronic wildfire around the globe, with it were propagated, perhaps misconceived, assumptions as to the origins and consequences of financial crises in other economies. Television coverage of a grandstanding U.S. congressman (on the eve of seeking re-election) picked up the phrase "greed and corruption on Wall Street." Within hours, Australia's Prime Minister (his speech writer obviously having watched television the night before) lambastes "greed and lax regulation" in Australia. ${ }^{30}$ Irrespective of the prevalence - or not - of greed and corruption on Wall Street, had greed and lax regulation suddenly surged in Australia? Likely not.

\section{False Cognates and False Friends}

The relative resilience of some economies to the financial crisis may be partly explained by this phenomenon. A bank is a bank, and a mortgage is a mortgage, from Los Angeles to Toronto to Adelaide. Or

are sometimes considered cognates when in fact they are not. Even if false cognates lack a common root, there may still be an indirect connection between them.” False Cognate, WIKIPEDIA, http://en.wikipedia.org/wiki/False_cognate (last modified Feb. 15, 2011, 3:44PM). "False friends (or faux amis) are pairs of words or phrases in two languages or dialects (or letters in two alphabets) that look or sound similar, but differ in meaning. The term should be distinguished from "false cognates," which are similar words in different languages that appear to have a common historical linguistic origin (whatever their current meaning) but actually do not.” False Friend, WIKIPEDIA, http://en.wikipedia.org/wiki/False_friend (last modified Feb. 14, 2011, 10:50AM).

30. Michelle Grattan \& Julia Medew, Rudd War on Bankers’ Deals, The AgE (Austl.), Oct. 16, 2008, at 1, available at http://www.theage.com.au/national/rudd-war-on-bankerssalary-deals-20081015-51jz.html. 
are they? Share prices in Canadian banks plummeted at the height of the crisis, seemingly infected by financial crisis flu. Yet Canadian banks had not engaged in the lending practices which brought low U.S. mortgage lenders and the structural weaknesses of the fragmented U.S. banking system were not present in Canada. ${ }^{31}$ These differences, this information, however, took much longer to percolate through the collective investment consciousness than the cry of fire which had set markets tumbling. But when the more accurate assessment of risk gained greater currency, economies such as Canada and Australia appeared more "resilient" to the crisis.

The point here is that instantaneous information flows may in fact propagate the equivalent of false cognates or false friends, creating a "problem" where none existed, or leading to misinterpretation of a very real problem. In time, cooler heads may prevail and the existence or sources of such problems themselves be reconsidered.In the interim, however, an inappropriate regulatory response, also propagated by international information flows, may have taken root. ${ }^{32}$ Information does drive markets, but not necessarily to the most obvious or most desirable destination.

\section{B. Chaos and Path Dependency}

It is anomalous that a country such as the United States, noted, and justly so, for its dynamic financial system, full of genius and innovation, should be burdened with such a difficult and obviously deficient regulatory regime. But that is the case. Part of the problem is the political and legislative system, with its exquisite checks and balances, and the key role played by lobbyists. It is not that this system is any better or worse than any other. It does, however, make legislative and regulatory reform in complex areas, such as finance, a slow and arduous process, except possibly in times of crisis. ${ }^{33}$

31. Canadian banks, though, are international institutional investors and, as such, did find "toxic assets" in their investment portfolios.

32. For example, the notorious Sarbanes-Oxley Act of 2002, Pub. L. No. 207-204, 116 Stat. 745 (codified as amended in sections of 15 U.S.C. and 18 U.S.C.), passed in the United States, provoked a rash of look-alike legislative and other initiatives around the world. See, e.g., Tobias Buck, EU Company Auditing Proposal is Toned Down After Protests, FIN. Times (U.K.), June 22, 2005, at 2 (discussing the defeat of a proposal in the European Parliament to require audit committees on a pan-European basis).

33. Some financial sector reforms in the U.S., such as abolition of the McFadden Act and the Glass-Steagall Act, took decades. William L. Megginson \& Scott B. SMart, 
At the heart of this financial crisis is the fragmented, inefficient banking system and its regulation in the United States. There are thousands of credit institutions, of various kinds, each subject to a multiplicity of regulators. Opportunities for regulatory arbitrage, lax oversight, and imprudent practices leading to systemic failures abound. There is nothing new here. The same industry, mortgage lending, was the center of the savings and loans crisis in the 1980s, which resulted in a public rescue effort in the form of the Resolution Trust Corporation.

Over a dozen years ago, possibly prompted by the earlier savings and loans crisis in the United States, Mark Roe ${ }^{34}$ examined the U.S. financial system through the prism of chaos theory, concepts of path dependency, and evolutionary biology. ${ }^{35}$ The argument was a counterpoint to prevalent law and economics views of the U.S. market inspired by the efficient market hypothesis. $^{36}$

In looking at the U.S. financial system, Roe noted:

[W] hat survives depends not just on efficiency but on the initial, often accidental conditions (chaos theory), on the history of the problems that had to be solved in the past but that may be irrelevant today (path dependence), and on evolutionary accidents - what might do best today could have been selected out for extinction in the past. ${ }^{37}$

The nature of financial institutions and their regulation in the United States are hard to change. The institutions and their regulation date back, not just decades, but to decisions made early in the nation's history. Not only did the United States break away politically from Britain in the late eighteenth-century, but it also broke away from British legislative and institutional traditions-including the British banking system.

INTRODUCTION TO CORPORATE FINANCE 455 (2d ed. 2008). Others, such as a comprehensive reform of securities regulation, the so-called "aircraft carrier" proposals of 1998, never saw the light of day. Id.

34. Now at Harvard Law School.

35. Mark Roe, Chaos and Evolution in Law and Economics, 109 HARV. L. REv. 641, 641 (1996).

36. It is difficult to overestimate the importance of the efficient market hypothesis over the last several decades. It is now undergoing serious questioning, see Efficiency and Beyond, supra note 5, but its tenets have been such an accepted part of financial market theory that not only do they implicitly underpin regulatory initiatives, but are actually made explicit in statutory provisions. For example, in the United States., the Securities Act of 1933 provides that "[w]henever pursuant to this title the Commission is engaged in rulemaking and is required to consider or determine whether an action is necessary or appropriate in the public interest, the Commission shall also consider, in addition to the protection of investors, whether the action will promote efficiency, competition, and capital formation.” 15 U.S.C. $\$ 77 b(b)(2000)$.

37. Roe, supra note 35 , at 641 . 
The fragmented, small local banking system (and the seeds of the present global financial crisis), originated in the 1830s. "Andrew Jackson's destruction of the Second Bank of the United States... yielded weak financial institutions that today would be out of place in America, which is now a nation of large businesses and which could well absorb large-scale finance., ${ }^{38}$ According to Roe, U.S. capital markets developed to the extent they have to compensate for the inefficiencies of the banking institutions. ${ }^{39}$ So it is not surprising, in the overall scheme of the U.S. financial system, to see the creation of financial products (those "toxic assets") which transfer risk from the banking sector to the capital markets.

Chaos theory does provide some intriguing insights into the current financial crisis. As Roe suggests, dysfunctional aspects of the current system of financial regulation in the United States, closely tied to this financial crisis, may be traced back to those initial conditions, decisions as to structure and regulatory philosophy of the early nineteenth-century. But the "butterfly effect" of chaos theory also appears to be operatingthe exponential growth of perturbations from a small change in initial conditions. This suggests that international financial markets are now operating as a closed system, according to set rules producing predictable results, the rationality suggested by Teubner.

There are several implications to this observation. First, why did so few people see it coming? ${ }^{40}$ After all, the FSF, created in the aftermath of the Asian financial crisis, was dedicated to promoting international financial stability, as its name implies. ${ }^{41}$ Was the approach of the FSF, and its uncritical reliance on a hodgepodge of international standards, in the assessment of the stability of financial systems, fundamentally flawed? Second, are there lessons to be learned from the resilience of

38. Id. at 644 .

39. See Roe, supra note 35, at 645.

40. With the benefit of hindsight, of course, there were the prescient few. "The banking world ignored Gillian Tett when she predicted the credit crisis two years ago." See Laura Barton, On the Money, GuARDIAN (U.K.), Oct. 31, 2008, at 12, available at http://www.guardian.co.uk/business/2008/oct/31/creditcrunch-gillian-tett-financial-times.

41. As a tacit admission of its blatant failure, the Financial Stability Forum has been renamed the Financial Stability Board, and work is in progress to reformulate its mission. See Press Release, Financial Stability Forum re-established as the Financial Stability Board, FIN. STABILITY F. (Apr. 2, 2009), www.financialstabilityboard.org/press/ pr_090402b.pdf. 
certain economies? Will these lessons be taken to heart by the successor institution to the FSF, the recently constituted Financial Stability Board?

\section{CONTAGION AND PREDICTABILITY}

The United States caught pneumonia; Canada and Australia got the sniffles. The seeming resilience of some economies, such as those of Australia and Canada, to the worst of the financial crisis puts into question at least some aspects of the international best practice and international standards approach endorsed by the FSF. The FSF supports the Financial Sector Assessment process conducted by the IMF and the World Bank. Although it maybe too soon to judge whether the resilience demonstrated by Canada and Australia is real or a temporary mirage, it does suggest that diversity (like the rain forest for the planet) is a good thing for financial systems.

A second issue is the failure of the FSF to predict, much less avoid, the financial storm that was brewing. The following sections of this paper will attempt to tease out some tentative reasons for this failure, and its implications for the future.

\section{A. The Role of the FSF and the FSAP}

Chaos theory, as applied to financial systems, would suggest that crises, like hurricanes, are predictable. The question then is why so many were caught unawares by this one, and in particular, the FSF. The FSF was created in the aftermath of the Asian financial crisis of a decade earlier specifically to detect "vulnerabilities" in financial systems and serve as an early warning system; it was caught flat-footed. ${ }^{42}$

This was despite the mass of information collected by bodies such as the IMF and the World Bank pursuant to the FSF-mandated FSAP. It is hard to escape the conclusion that the FSAP, conducted on a country by country basis using various international standards, were, at least to a certain extent, asking the wrong questions. Initial conditions were not being correctly identified and regulatory responses were being misinterpreted.

The widespread adoption of such top-down, assumption-riddled standards and their use as indicators of potential financial instability, should have been put into serious question by this financial crisis. Unfortunately, judging from the initial responses, there is a risk of more of the same, just more of it. "Broader reform could be achieved by creating a ministerial body with decision-making powers not inside but above the [International Monetary] Fund. It would also be responsible

42. See Arner \& Taylor, supra note 3, at 490. 
for political supervision of the other international institutions, including the World Bank, the Financial Stability Board, and the World Trade Organisation." 43 Such suggestions are a variation on the "World Financial Authority" idea floated several years ago by Eatwell and Taylor, ${ }^{44}$ and recently called an "unrealistic yet notorious-proposal." 45 It is hard to escape the conclusion that promotion of simplistic, high level, "solutions" to complex and deep-rooted structural problems in various parts of the global financial system are "quick fixes." 46

\section{The FSF and Soft Law}

The FSF was envisaged as a "grouping of technocratic authorities with relevant expertise and experience." "77 Representatives of central banks and ministries of finance met on a regular basis with a view to promoting convergence to minimum standards in the form of "soft law," with compliance by force of example and moral suasion. ${ }^{48}$ For the implementation phase, the IMF and the World Bank were recruited to carry out financial sector assessments on a country by country basis.

The financial crisis, however, raises serious doubts as to the utility of these exercises and painfully highlights the ineffectiveness of the FSF. As Arner and Taylor point out, the crisis has put into question the international "soft law" approach and the workings of "policy networks." 49 With the FSF, it was "not at all clear what action will

43. Timothy Adams \& Arrigo Sadun, Op-Ed., Global Economic Council Should Oversee All, Fin. Times (U.K.), Aug. 16, 2009, at 9.

44. See John Eatwell \& Lance Taylor, A World Financial Authority, in InTERNATIONAL CAPITAL MARKETS: SYSTEMS IN TRANSITION 17 (2002).

45. Régis Bismuth, The Independence of Domestic Financial Regulators: An Underestimated Structural Issue in International Financial Governance, 2 GoETTINGEN J. INT’L L. 93, 108-09 (2010).

46. "Admittedly, the G20 has entrusted the Financial Stability Board with the mission of monitoring the standard-setting activity and has mandated the Basel Committee, IOSCO and the IAIS (among others) with the task of developing new rules. However, this choice seems more a quick-fix than a sustainable strategy. It will neither preserve state unity on the international stage, nor solve the issues of circumvention of national and regional democratic processes.” Id. at 108.

47. Arner \& Taylor, supra note 3, at 491. See also Enrique R. Carrasco, Crisis and Opportunity: How the Global Financial Crisis May Give Emerging Economics Greater Voice in International Finance via the Financial Stability Board 8-10 (Univ. of Iowa Legal Studies, Research Paper No. 09-43, Dec. 2009); available at: http://papers.ssrn.com/sol3/ papers.cfm?abstract_id=1477975.

48. Arner \& Taylor, supra note 3, at 489.

49. Id. at 491 . 
follow ... or, indeed, who will act." ${ }^{50}$ Eatwell called the FSF a "think tank with nowhere to go." ${ }^{\text {"1 }}$ Not only did the FSF toil in obscurity, it was "invisible." 52 The obscurity of the FSF, its private membership, may have detracted from its perceived legitimacy. ${ }^{53}$

The invisibility of the FSF was related to its predilection for "soft law" approaches. Lacking the transparency and contestation ${ }^{54}$ of the legislative process, soft law is easy. Everything happens behind the scenes, away from the glare of the press and the inconvenience of serious questioning. Consensus rules, and since it must, hard questions go unadressed. The product of the soft law process has an airy vagueness to it, lacking in the detail and sharp edges of legislation.

"Hard law" is hard. Making law can be a messy, fraught process (sometimes compared to sausage making); a hard slog on the technical details; hard choices on difficult or controversial issues. Sometimes the result is less than optimal-think Sarbanes-Oxley Act of $2002^{55}$ which was a rushed response to a perceived crisis; and other times, the result can be brilliant and enduring - think the French Civil Code. But the process, in the democracies and elsewhere too, is a relatively public process, and one open to contestation.

But even "soft law" has shown some arthritic symptoms. In theory, one of the advantages of soft law is said to be that it can be easily changed, responsive to fast moving events, given that it bypasses the time-consuming legislative process. But that has not necessarily been the case; path dependency operates to preserve the less than optimal elements of soft law as well as hard law.

The International Organization of Securities Comissions' (IOSCO) Objectives and Principles of Securities Regulation, one of the FSFmandated international standards discussed below, is an example. ${ }^{56}$ To its credit, the Organisation for Economic Co-operation and Development (OECD) has been much more proactive in learning from experience with

50. John Eatwell, The Challenges Facing International Financial Regulation, Paper Presented at the Western Economic Association International Conference, at 14 (July 48, 2001), available at http://www.financialpolicy.org/DSCEatwell.pdf.

51. Id.

52. See Barton, supra note 40.

53. See Bismuth, supra note 45, at 108 (arguing that the FSF and FSB approach amounts to a "circumvention of national and regional democratic processes").

54. See Arner \& Taylor, supra note 3, at 494.

55. See 15 U.S.C. $\S 7201$ (2006).

56. Objectives and Principles of Securities Regulation, Int’l Org. Sec. CommISsIONS, (2003), available at www.iosco.org/library/pubdocs/pdf/IOSCOPD154.pdf. 
principles which it devises, such as the OECD Principles of Corporate Governance, another of the FSF-mandated international standards. ${ }^{57}$

\section{The FSAP Experience}

Implementation of the FSF agenda focused primarily on the use of the FSAP, the Financial Sector Assessments conducted by the IMF in developed economies, and jointly by the IMF and the World Bank in developing economies. The mandate was to identify "vulnerabilities" in financial systems, on a country by country basis, with a view to nipping financial crises in the bud. In particular, priority was to be given to systematically important countries. The FSF identified tweleve international standards to be used in the process of "benchmarking" or "rating" a financial system. ${ }^{58}$

The FSAPs produced a veritable gold mine of data over time. ${ }^{59}$ Unfortunately, some of the data is of dubious reliability and quality, for a number of reasons. The international standards themselves are not of the same caliber. Among the twelve international standards chosen by the FSF, there is overlap, duplication, and inconsistency. The methodology of the FSAP process was in a constant state of flux. The teams themselves conducting the FSAPs varied in expertise and sophistication. Querelles de chapelle $^{60}$ between the IMF and the World Bank teams were not unheard of.

Nevertheless, the data accumulated was impressive; the difficulty has been that it cannot be used in a narrow, scientific way, given its deficiencies. Rather, it needs a kind of qualitative interpretation which has not always been possible. With hindsight, some of the observations appear spot on. Iceland was identified as vulnerable as far back as 2002.

57. ORg. FOR ECON. CO-OPERATION \& Dev., OECD PRinciples of CoRporate GOVERNANCE (2004), available at http://www.oecd.org/dataoecd/32/18/31557724.pdf. (last viewed on Nov. 17, 2010).

58. See 12 Key Standards for Sound Financial Systems, Fin. StaBiLITY BD., http:// www. financialstabilityboard.org/cos/key_standards.htm.

59. This huge volume of data does not seem to find its way readily into the academic literature, although several people at the IMF, in particular, Jennifer Elliott, have laudably been publishing papers making use of the data. See, e.g., Ana Carvajal \& Jennifer Elliott, The Change of Enforcement in Securities Markets: Mission Impossible (Int'l Monetary Fund, Working Paper No. 09/168, Aug. 2009), available at http://ssrn.com/abstract=1457591 (last viewed Nov. 17, 2010).

60. The expression refers to pointless internal disputes and rivalries within an organization. 
The importance of supervision and risk assessment of large, complex financial institutions was also recognized early on. Difficulties with some of the standards, such as the IOSCO Objectives and Principles of Securities Regulation (IOSCO Principles), were noted. ${ }^{61}$ Given the volume of data and its variable quality, however, important observations may have been lost in the "noise."

\section{B. Inadequacies of the FSAP Experience}

Most importantly, the FSAPs were sometimes asking the wrong questions, failing to identify the operative "initial conditions" important to chaos theory and thus the direction and magnitude of the perturbations to follow. Some international standards failed to differentiate among financial markets in different parts of the world, or to recognize the stratification of any one particular market. Financial markets, even internal domestic ones, are not monolithic. Most ironically, for standards billing themselves as "international," many of the standards employed completely missed the international and cross-border aspects of financial markets. This was due to the fact that many of the so-called "international" standards were simply reheated domestic regulation, which did not look to international dimensions of an issue.

\section{Problems with Execution of the FSAP Exercises}

Both the IMF and the World Bank periodically engage in evaluations of their work product; the FSAPs, like other programs, have been subjected to critical internal scrutiny. In 2006 an evaluation of the FSAP program $^{62}$ by the IMF noted that there had been an improvement in the quality of execution but that the program was at a "critical crossroads." 63

Inconsistencies in execution and results persisted despite the introduction of detailed "methodologies." The quality of the data itself was not subject to rigorous enough scrutiny. One continuing problem was the "parachute" approach; the IMF teams of experts, including the World Bank if involved, parachuted in and out of countries, never spending enough time to absorb country specific circumstances. Some analysis and "ratings" indicated a

61. They are not designed to identify systemic risk; rather they focus on investor protection and traditional structures of a securities regulatory regime.

62. INDEP. EVALUATION OFFICE, INT'L MONETARY Fund, REPORT ON THE EVALUATION OF THE FinANCIAL SECTOR AssESSMENT PROGRAM 6-7 (Jan. 5, 2006), available at http:// www.imf.org/external/np/ieo/2006/fsap/eng/pdf/report.pdf. See also InT'L MONETARY FUND \& World Bank, The Financial Sector Assessment Program after Ten Years: EXPERIENCES AND REFORMS FOR THE NEXT DECADE (Aug. 28, 2009), available at http:// www.imf.org/external/np/pp/eng/2009/082809B.pdf (subsequent review of FSAP).

63. INDEP. EVALUATION OFFICE, supra note 62, at 6. 
"check the box" mentality, ${ }^{64}$ more egregiously manifesting itself in standardized advice being given, irrespective of the country involved. ${ }^{65}$ In the words of the 2006 IMF evaluation, "overly simplistic" messages were being conveyed with respect to the strength of the financial system in any one country. The evaluation called for more subtle interpretation of the results which could form the basis of "health warnings."

A more controversial aspect of the FSAP experience, and one which may account for the inconsistencies and variability of the results, focuses on the level of technical skills within the IMF (and the World Bank) to conduct the exercises. A former member of the executive boards of the IMF and the World Bank groups points to the "various recent independent evaluations [that] have noticed the persistence of technical and organizational weaknesses that impair the IMF's ability to integrate macroeconomic and financial sector analyses, and to draw credible risk indications from them... Notwithstanding follow-up action from the IMF, the opinion remains today widespread that the technical skills of its economists are inadequate to understand the financial markets, and to appreciate how they interact with the real economy."

One obvious difficulty with the technical proficiency of IMF (and World Bank) staff conducting FSAPs has perhaps been too obvious to merit mention in the critiques of the process. Financial regulation is law, and law of a particularly technical kind, strongly influenced by practitioners of the financial arts and massaged by political process. ${ }^{67}$ In the area of capital markets regulation in particular, economists, for better or for worse, are conspicuously absent from the law-making processes. The IMF and the World Bank, on the other hand, are institutions bursting at the seams with economists. A few lawyers operate undercover, disguising themselves as financial or private sector specialists, and outside consultants,

64. Id. at 11 (referring to a "checklist approach").

65. A possibly apocryphal story circulated at one time that sometimes the same advice was given, country by country, without even a change in the name of the country.

66. Biagio Bossone, The IMF, the U.S. Subprime Crisis, and Global Financial Governance, VoxEU (Feb. 3, 2009), http://www.voxeu.org/index.php?q=node/2973. Bossone cites several examples of IMF statements in 2007 which indicate obliviousness to the impending financial disaster: “. . . . in the summer of 2007, the IMF staff indicated that in the United States "[c]ore commercial and investment banks are in a sound financial position, and systemic risks appear low'[citation omitted].” Id.

67. It is notable that during the period leading up to the global financial crisis, the World Bank was winding down its Financial Sector Development Vice-Presidency. Some of the first professionals to go were those with legal training. 
who may incidentally (and, incidentally is the operative word here) have legal training, are often brought in to participate in the FSAP exercises. ${ }^{68}$

However, within the IMF and the World Bank, the process and results of the FSAP exercises remain dominated by an academic and somewhat "econocentric" view of the financial world. Internal legal expertise is scarce (most of the financial sector legal expertise being concentrated in internal Treasury and co-financing operations). Despite the reams of advice dispensed as to regulatory reforms in the financial sector, one would be hard pressed to find more than a handful of staff in these institutions who have actually read, much less fully understood, a comprehensive set of financial sector regulations, such as the U.S. securities regulatory regime (which has served as model to innumerable reforms propagated around the world).

There are several implications resulting from this paucity of legal expertise applied to financial sector initiatives at the IMF and the World Bank. Lawyers dominate the operation of many financial regulatory regimes around the world - as well as being responsible for creating them. Economists and lawyers often have difficulty communicating with one another, given the assumptions and confines of their intellectual and professional frameworks.

The other implication may be explanatory of the sometimes inept use to which international standards have been put and the conclusions drawn from their inexpert application (the "check the box" mentality observed by the independent evaluations of the FSAP process). Some international standards, such as the IOSCO Principles, were originally developed by regulators (read lawyers), for use by other regulators (read lawyers) in the creation or critical self-assessment of regulatory regimes (read law). They were not designed for use by non-professionals and pre-date the FSAP exercises. There may even have been some dismay on the part of various IOSCO committee members (regulators all), as to the amateurish uses to which their principles were being put in the FSAP exercises. In any event, in 2003, IOSCO created a detailed "methodology" to accompany the IOSCO Principles, targeted largely to FSAP participants, in an effort to maintain the integrity of interpretation and promote a more informed use of the principles.

The number of codes and standards used in the FSAP process has also been a problem. As noted above, the standards varied greatly in their

68. World Bank and IMF legal departments are primarily service departments for the internal governance and operational activities of the institutions. In the last decade, some efforts have been made to broaden the scope of activities, at least at the World Bank, by the creation of various thematic groups with more specialized expertise, in addition to the groupings of lawyers organized by region. 
origins and level of sophistication and continue to demonstrate overlap and inconsistencies. Inadequate integration of the results diminished their relevance. As the "ratings" of countries on various standards began to circulate publicly, countries began "gaming" the system, by enacting legislation or adopting measures that would "tick the boxes" without necessarily being of any effect. ${ }^{69}$

As well, the voluntary nature of the FSAP process was problematic. Canada, that boy scout of the international world, was the first country to volunteer, some say to its chagrin. ${ }^{70}$ However, as of the date of the 2006 IMF evaluation, "some 20 to $25 \%$ of countries that are 'systemically important' and/or have vulnerable financial systems - two key criteria endorsed by the IMF and the World Bank Boards-have not been assessed." 71 As of 2006, four systemically important countries in particular stood out: Turkey, Indonesia, China, and most importantly of all, the United States. ${ }^{72}$

In reacting to criticism that it did not see the global financial crisis coming, the IMF identified the failure of the United States to volunteer for an FSAP as a major factor. ${ }^{73}$ The United States, for its part, had justified its objections to participating in the FSAP, by invoking the heavy burden such an assessment would place "on the scarce resources of the [IMF]."74

It may seem curious that the United States, which in fact was a driving force behind many of the international standards (sometimes for

69. See Curtis J. Milhaupt \& Katharina Pistor, LaW and Capitalism: What CoRPORATE CRISES REVEAL ABOUT LEGAL SYSTEMS AND ECONOMIC DEVELOPMENT AROUND THE WORLD 47-173 (2008). See also Cally Jordan, The Conundrum of Corporate Governance, 30 BROOK. J. INT'L L. 983 (2005) (discussing Germany's introduction of a voluntary code of corporate governance).

70. Canada's financial system, the star of the current financial crisis, was assessed as being somewhat deficient when benchmarked against international standards.

71. INDEP. EVALUATION OFFICE, supra note 62, at 7.

72. Turkey subsequently volunteered and the US finally permitted an FSAP to be conducted in the wake of the global financial crisis.

73. "The Fund has also deflected criticism of its failure to predict the crisis. Because the United States refuses to be subject to an IMF Financial Sector Assessment Program (FSAP), Managing Director Strauss-Kahn argues, the Fund cannot be responsible for a lack of supervision. The FSAP is one of the IMF's main supervisory instruments, and it was not employed in the United States during the lead-up to the crisis.” Laurie Glapa, The IMF Faces Post-Crisis Criticism, UnIV. OF IOWA CENTER FOR INT’L FIn. \& DeV. (Oct. 15, 2009, 2:48 PM), http://uicifd.blogspot.com/2009/10/imf-faces-post-crisis-criticism.html.

74. Bossone, supra note 66 . 
ideological and political reasons ${ }^{75}$ and whose regulatory framework defined the content of the standards themselves, ${ }^{76}$ for many years stubbornly resisted volunteering for a financial sector assessment. Putting aside tender concerns for the workload of IMF staff noted above, was this hubris, a misguided conviction as to the stability and superiority of the U.S. financial system? Was it a "we have nothing to learn from anyone else" response? Rather, did it reflect awareness of the problems in the domestic financial regulatory structure, but the view that these problems could be dealt with domestically given the vast resources at the disposal of the United States? Was the U.S. financial system considered too complex to tackle (and too big to fail)? Irrespective of the reasons, it is tragically ironic that the global financial crisis began as a failure in the domestic U.S. regulatory structure, and one which, despite the inadequacies of the various benchmarks and standards at the disposal of the IMF, would undoubtedly have been flagged by an FSAP. ${ }^{77}$

The essentially domestic focus of the FSAP process has also been singled out for criticism. Although "contagion" had been a marked phenomenon in the Asian financial crisis which led to the creation of the FSF and FSAPs, this was not an issue which was addressed in adequate manner by the FSAP process which ignored cross-border implications. As the 2006 IMF evaluation diplomatically put it: "Greater efforts by the IMF to distill common cross-country messages from the various FSAP exercises would be welcome."78

Finally, updating FSAPs, especially in view of the constantly evolving methodologies, was problematic. For any country, submitting to the highly intrusive, labor-intensive FSAP process was a chore and a burden; for smaller countries, or those with limited resources, handling the logistics involved in meeting the demands of large teams of financial experts, was a brutally exhausting exercise. And, like Canada perhaps, there were countries which felt they had been "burned” by the experience.

\section{Problems with the Substance of the FSAP Exercise}

The difficulties associated with execution of the FSAP program have been exacerbated by the substantive nature of some of the international standards (putting aside for the moment International Financial Reporting Standards and the BIS Capital Adequacy standards which

75. E.g., anti-money laundering (AML) and combating financing of terrorism (CFT).

76. See, e.g., IOSCO, OBJeCtIVES AND PRINCIPLES OF SECURITIES REgUlation (2003), available at http://www.iosco.org/library/pubdocs/pdf/IOSCOPD154.pdf.

77. Arner \& Taylor, supra note 3 , at 495 (stating that the FSAP process was not designed to deal with U.S. domestic problems in a predictive fashion or otherwise).

78. INDEP. EVALUATION OFFICE, supra note 62, at 5. 
have a long history behind them). Some of the standards, unfortunately, have swallowed whole the precepts of an influential but misguided body of literature, usually referred to as the "law and finance" literature, which has subsequently been widely criticized on both the law and finance sides. ${ }^{79}$ As noted earlier, some "international" standards are not international at all, but rather reheated domestic, often U.S. domestic, law. The weakness, in this case, is that such standards are riddled with the hidden assumptions and deficiencies of their country of primary origin. And where that country of origin is the United States, implementing such standards (as is the ultimate goal of the FSAP exercise) may mean adopting inappropriate and suboptimal regulatory approaches.

For example, take the IOSCO Principles, one of the twelve international standards mandated by the FSF, and referred to on several occasions above. Originally formulated in 1998, in the shadow of the Asian financial crisis, the IOSCO Principles are backward looking, taking as their point of departure the institutions and regulatory framework of the United States, as it existed in the mid-1990s. It is useful to cast one's mind back to the capital markets of the 1990s, to consider how dramatically the world has changed, and, how dated the IOSCO Principles are. At the time of their original formulation, for example, Dick Grasso was still reigning over the New York Stock Exchange and its open outcry trading floor. The idea of a transatlantic merger of the venerable old dame with the continental consolidated exchange, Euronext, would have been unthinkable. Alternative trading systems and online trading were just in their infancy.

The IOSCO Principles, because they looked to the U.S. markets and regulation of the 1990s, subsumed the hidden assumptions of the time and place, assumptions which lie deeply buried in their originating conditions, and are rarely explicitly acknowledged. First, there is the 1930s emphasis on retail investors and equity trading. Derivatives, of course, are not on the radar screen (for the most part, they do not come under the regulatory scope of the U.S. Securities and Exchange Commission), and debt markets virtually ignored (derivatives are usually structured as debt instruments). The "unregulated" or private placement markets (wherein hedge funds lurk) are also ignored, having received

79. The "law and finance" literature is voluminous. See generally Holger Spamann, 'Law and Finance' Revisited, (Harv. Law Sch. John M. Olin Ctr. For Law, Econ., \& Bus., Discussion Paper No. 12, Feb. 2008), http://ssrn.com/abstract=1095526. 
perfunctory treatment in the 1930s legislative framework which still governs in the United States. Securities were still pieces of paper in the 1930s, and the U.S. regulation continues to play catch up in terms of recognizing the implications of the electronic age. Faith in selfregulatory market institutions remains a deeply entrenched notion in the United States and the efficient market hypothesis (a theory now somewhat battered by the crisis) formally acknowledged in U.S. securities legislation. ${ }^{80}$ Finally, U.S. regulation is notoriously domestically focused.

These features of U.S. securities regulation shine through the IOSCO Principles. They are also the areas of weaknesses, in terms of where the global financial crisis exerted its greatest pressures. Utilizing the IOSCO Principles, the FSAP process, even at the best of times, would have detected these pressure points with difficulty. ${ }^{81}$

For many years there had been a somewhat puzzling reluctance on the part of IOSCO to seriously revisit the IOSCO Principles. ${ }^{82}$ In the years

80. See 15 U.S.C. § 77b(b) (2006) (“Consideration of Promotion of Efficiency, Competition and Capital Formation-Whenever pursuant to this title the Commission is engaged in rulemaking and is required to consider or determine whether an action is necessary or appropriate in the public interest, the Commission shall also consider, in addition to the protection of investors, whether the action will promote efficiency, competition, and capital formation.”).

81. Although there is little doubt that other standards and assessments would have detected some of the greater institutional and regulatory weaknesses in the U.S. banking system.

82. In June 2010, IOSCO announced a major revision to the IOSCO Objectives and Principles of Securities Regulation, “. . . to incorporate eight new principles based on the lessons learned from the recent financial crisis and subsequent changes in the regulatory environment, which are designed to strengthen the global regulatory system against future crises. The eight new principles cover specific policy areas such as hedge funds, credit rating agencies and auditor independence and oversight, in addition to broader areas including monitoring, mitigating and managing systemic risk; regularly reviewing the perimeter of regulation and requiring that conflicts of interest and misalignment of incentives are avoided, eliminated, disclosed or otherwise managed.” Media release, IOSCO, Global Securities Regulators Adopt New Principles and Increase Focus on Systemic Risk, IOSCO/MR/10, (June 10, 2010), http://www.iosco.org/news/pdf/IOSCONEWS188.pdf [hereinafter IOSCO Media Release].

The eight new principles are:

- "Principle 6: The regulator should have or contribute to a process to monitor, mitigate and manage systemic risk, appropriate to its mandate;

- Principle 7: The regulator should have or contribute to a process to review the perimeter of regulation regularly;

- Principle 8: The regulator should seek to ensure that conflicts of interest and misalignment of incentives are avoided, eliminated, disclosed or otherwise managed;

- Principle 19: Auditors should be subject to adequate levels of oversight;

- Principle 20: Auditors should be independent of the issuing entity that they audit;

- Principle 22: Credit rating agencies should be subject to adequate levels of oversight. The regulatory system should ensure that credit rating agencies whose ratings are used for regulatory purposes are subject to registration and ongoing supervision; 
between 1998 and 2010, there had been certainly enough experience with implementation and assessment (through self-assessments under the auspices of IOSCO itself as well as the FSAP process) to make the limitations of the IOSCO Principles obvious. But rather than reconsidering the substance in light of the recognition of new market conditions and regulatory approaches, there was fiddling at the margins, revisions to "methodology." 83 Revisions in 2008, according to IOSCO, were absolutely identical to $2003 .{ }^{84}$

Could it be that the reluctance to completely revisit the IOSCO Principles derived in part from the transformation of the "soft law" principles into hard law regulation, in country after country in response to FSAP recommendations? ${ }^{85}$ It would be somewhat embarrassing for the IMF and the World Bank teams to return to these countries, acknowledging perhaps that the IOSCO Principles were not optimal, for these countries' markets, or any other modern markets for that matter.

Even the revisions announced June 10, 2010, while adding eight new principles "based on the lessons learned from the recent financial crisis and subsequent changes in the regulatory environment,",86 do not revisit the original thirty principles and their underlying assumptions. Importantly, the eight new principles do recognize that the "financial markets which IOSCO members regulate, or may be exempt from regulation, can be the mechanism by which risk is transferred within the financial system" (emphasis added). ${ }^{87}$ Unregulated markets finally appear on the radar screen, and the markets themselves - not just institutions-are recognized as systemically important.

Criticism of the IOSCO Principles is not, in any way, to suggest that IOSCO itself has been a flawed initiative. Quite to the contrary, IOSCO has been a resounding success. Its significance to international capital markets has been growing by leaps and bounds, and its members

- Principle 23: Other entities that offer investors analytical or evaluative services should be subject to oversight and regulation appropriate to the impact their activities have on the market or the degree to which the regulatory system relies on them; and

- Principle 28: Regulation should ensure that hedge funds and/or hedge funds Id. managers/advisers are subject to appropriate oversight."

83. See discussion supra at p. 21.

84. See infra note 103 .

85. This is to say nothing of the "country rankings" based on the FSAP exercises.

86. IOSCO Media Release, supra note 82.

87. Id. 
increasingly convinced of the importance of its mission. IOSCO saw the crisis coming ${ }^{88}$ and continues to produce topical and informed reports on a wide variety of timely issues, such as practices and requirements for asset-back securities, exchange traded funds, collective investment schemes, and unregulated markets. ${ }^{89}$

Nevertheless, the original thirty IOSCO Principles remain untouched, an example of path dependency in action perhaps. IOSCO has been working around them, addressing significant issues outside the original IOSCO Principles, in new initiatives and reports, as well as by the addition of the eight new principles. The assumptions underlying the eight new principles, however, are different ("regulation" has dethroned both the "efficient market" and "self-regulation"), thus creating certain internal tensions within the enlarged set of principles. ${ }^{90}$ For example, the limitations of self-regulation in particular (one of the IOSCO Principles), are openly critiqued in the 2009 Unregulated Markets study as "typically voluntary and the standards lack regulatory status and consistent implementation. Moreover, neither the industry initiatives nor market discipline averted the deficiencies that contributed to the global financial crisis." 91 Such candour is refreshing and bodes well for a more critical look at international standards.

But the IOSCO Principles, old and new, remain at the heart of the FSAP exercise, which brings us back to contagion and predictability. The FSF and the FSAPs did not address contagion issues. Neither did they predict the global financial crisis. They were asking the wrong questions, looking in the wrong directions, and, blinded by the glare of international standards, failed to appreciate the complexity and diversity of financial markets and the problems posed by their regulation.

88. In May 2008, the Technical Committee of IOSCO had already published a report on the matter. See TeChnicAl Comm., IOSCO, Report of the TASK ForCE ON THE SUBPRIME CRISIS (2008), available at http://www.iasplus.com/iosco/0805ioscosubprime report.pdf.

89. The full range of current IOSCO initiatives may be consulted on the IOSCO home page. IOSCO, http://www.iosco.org/ (last visited Feb. 22, 2011).

90. See Technical Comm., IOSCO., Unregulated Financial Markets and PRODUCTS 3 (2009), available at http://www.iosco.org/library/pubdocs/pdf/IOSCOPD301.pdf (“. . . all systemically important financial markets and instruments should be subject to an appropriate degree of regulation and oversight, consistently applied and proportionate to their local and global significance.”). The report acknowledges both the existence of the unregulated markets, and their importance particularly to international markets; in fact, that unregulated markets are at the origins of the international capital markets as well as the complexity of the issues involved. See id.

91. Id. at 5. 


\section{CONCLUSION}

In April 2009, the Group of Twenty (G-20) announced the creation of a successor institution to the FSF, the new Financial Stability Board (FSB), to be housed at the Bank for International Settlements (BIS) headquarters in Basle, Switzerland. The immediate question is the extent to which the FSB can overcome the legacy of the FSF.

On the face of it, the FSB is attempting to address certain criticisms directed towards the FSF. Certainly it has made an effort to be visible in the public eye. Membership has been expanded to a larger number of countries so as to include China and Indonesia, two of the three holdouts in the "systemically important" category of financial economies. The private club will no longer be quite so exclusive, or reclusive. There is a specific mandate to promote financial stability, but there is nothing new there. What is new, however, is that members have agreed to a planned "peer review" of their financial systems, overcoming the drawbacks to the voluntary FSAP process, at least with respect to members of the FSB.

The FSAP process, according to Mario Draghi in his April 2009 speech announcing the creation of the FSB, would continue apace. ${ }^{92} \mathrm{~A}$ few months later, in September 2009, the IMF and the World Bank, jointly, ${ }^{93}$ published a ten-year review of the FSAP process, featuring some "key" new approaches. ${ }^{94}$ In addition, "Early Warning Exercises" are to be conducted together with the IMF, which was announced at the FSB inaugural meeting in June 2009. "95 "Procyclicality" is now the

92. Mario Draghi, Chairman, Fin. Stability Forum, Re-establishment of the FSF as the Financial Stability Board, Remarks at the London Summit of the Financial Stability Board (Apr. 2, 2009), available at http://www.financialstabilityboard.org/publications/ r_090402.pdf. The IMF and The World Bank Boards published their latest review of the FSAP in September 2009. See MONETARY FUND \& WORLD BANK, supra note 62. The IMF and the World Bank, in reviewing the FSAP process, decided that in order to facilitate the integration of the stability assessment done in the context of FSAPs into IMF surveillance and the World Bank's financial sector work, a key innovation introduced by this review was the option to conduct FSAP updates in smaller, more flexible modules, focused on either stability or development aspects. See MONETARY FUND \& WORLD BANK, supra note 62, at 22 .

93. A joint publication is in itself an indication of greater cooperation and communication between the IMF and The World Bank.

94. See MONETARY Fund \& WORLD BANK, supra note 62.

95. In addition to the joint early warning exercises (EWEs) proposed by the FSB, the IMF is developing its own EWEs for large complex financial institutions (LCFI). Significantly, the "methodology builds on and will supplement current LCFI monitoring and analysis that is conducted through bottom up analysis of balance sheets" (emphasis in the original). See Thematic Review on Compensation, infra note 99, at 33. 
watchword of the day, that is, acting with a view to a "system wide approach to financial stability and embed a macroprudential orientation to regulatory and supervisory frameworks." ${ }^{\text {96 }}$ The goal is to induce a "race to the top" in the "implementation of international supervisory and regulatory standards." 97 To do so, the FSB has announced a "name and shame" program to publish the names of "non-cooperative jurisdictions" at the end of $2010 .{ }^{98}$

How the new FSB will differ from the FSF is unclear at this point. It is yet early, but the FSB still appears to be working at the margins. Its first review under the new FSB Framework for Strengthening Adherence to International Standards was completed in March 2010, a Thematic Review on Compensation. ${ }^{99}$ To consider the trivial political football of executive compensation as a priority in supporting financial stability in the midst of a global financial crisis is a bit like the band playing on as the Titanic sinks.

It is likely, however, that the FSB must be modest in its own initiatives. Staffing is limited, with many being relatively short term secondees, borrowed from other institutions. Its most important role may be to serve as a clearinghouse for the initiatives of others. Certainly a document which the FSB prepared in June 2010, Ongoing and Recent Work Relevant to Sound Financial Systems, ${ }^{100}$ could be an indication of this role. The document, over ninety pages in length, is a very useful compilation, with contact names and responsible authorities, summarizing dozens of diverse initiatives ongoing around the world. The FSB is, in fact, a minor player in this work, viewed as a whole together; the IMF and IOSCO feature prominently as responsible authorities. The heavy lifting will be left to them.

It would also not be surprising to find a central bank mentality pervading the institutional culture of the FSB, given its proximity to BIS and the background of its leadership. Capital markets and their regulation tend not to fall within a central banker's purview, yet they were the instrument of

96. FIN. STABILITY BD., REPORT OF THE FINANCIAL STABILITY FORUM ON ADDRESSING Procyclicality IN THE FinANCIAL SySTEM 8 (Apr. 2, 2009), available at http://www. financialstabilityboard.org/publications/r_0904a.pdf.

97. Press Release, Fin. Stability $\bar{B}$ d., Financial Stability Board Holds Inaugural Meeting in Basel (June 27, 2009), available at http://www.financialstabilityboard.org/press/ pr_090627.pdf.

98. See Press Release, Fin. Stability Bd., FSB Launches Initiative to Promote Global Adherence to International Cooperation and Information Exchange Standards (Mar. 10, 2010), available at http://www.financialstabilityboard.org/press/pr_100310.pdf.

99. See Thematic Review on Compensation, Fin. STABILITY BD. (Mar. 30, 2010), http://www.financialstabilityboard.org/publications/r_100330a.pdf.

100. See Cover Note by the Secretariat, Fin. Stability Bd., for the FSB Meeting, Ongoing and Recent Work Relevant to Sound Financial Systems, (June 14, 2010), available at http://www.financialstabilityboard.org/publications/on_1006.pdf. 
propagation of systemic risk on a transnational scale, this time round. Transmission of systemic risk through the global capital markets is what has made this crisis different.

The most notable legacy of the FSF, however, is the policy of the FSB to put continued faith in the use of a particular set of international standards, with all their demonstrated drawbacks. However, developments elsewhere may be producing more nuanced, sophisticated standards, and fostering a more adept application of them. The Chairman of the FSB, in addressing remarks in March 2010 to the Committee on Economic and Monetary Affairs of the European Parliament qualified the significance of international standards by declaring: "ultimately [it is] national and regional legislatures, accountable to their voters, that must decide and implement reforms." 101 Chairman Draghi may have been playing to his audience (the European Parliament, after all), but at the least is indicating awareness of the debates surrounding the undemocratic nature of the indiscriminate use of international standards. ${ }^{102}$

Another hopeful sign of a more nuanced approach to markets and standards is the Review of the Differentiated Nature and Scope of Financial Regulation-Key Issues and Recommendations ${ }^{103}$ published in January 2010 by yet another international association of international organizations - the Joint Forum composed of BIS, IOSCO and IAIS. The Joint Forum, unlike the FSB, is an association of regulators-banking, capital markets and insurance-with real life technical expertise. They understand that markets, institutions and regulation, domestic and international, are not monolithically the same.

If there can be any conclusions drawn at this point, it may be not to have unrealistic expectations of what may be accomplished by the FSB, and on the other hand, not to underestimate the nature and degree of change taking place.

101. Mario Draghi, Governor of the Bank of It., Chairman of the Fin. Stability Bd., Modernisation of the Global Financial Architecture-Global Financial Stability, Remarks before the Committee on Economic and Monetary Affairs of the European Parliament (Mar. 17, 2010), available at http://www.bis.org/review/r100318b.pdf.

102. See Bismuth, supra note 45, 94, 99-102 \& 105-08, 110 (discussing the bypassing of the democratic process resulting from adoption of international standards).

103. See generally Review of the Differentiated Nature and Scope of Financial Regulation, BASEL COMM. ON BANKING SuPERVISION (Bank for Int'l Settlements, Basel, Switz.), Jan. 2010, available at http://www.iaisweb.org/_temp/Review_of_the_Differentiated Nature_and_Scope_of_Financial_Regulation_January_2010.pdf. 
In particular, IOSCO is undergoing a marked transformation, on several fronts. Its members are now convinced of the significance of its role and prepared to devote more resources. There is a new operating structure being put in place, including a research function. Although the resource base of the organization, its national regulators, operate at a national level, there is less emphasis being placed on simply aggregating national experiences and more on developing a global perspective. Rather than focussing on systemic risk in the context of institutions, IOSCO will be looking at how international markets disperse risk. ${ }^{104}$

The financial industry too seems prepared to welcome an approach which is less reliant on top-down, assumption-ridden, one-size-fits-all international standards. Speaking last year in the Financial Times, ${ }^{105}$ Jim O’Neill, chief economist at Goldman Sachs stated:

\begin{abstract}
When everyone is suffering from what appears to be the same shock, the desire to implement a co-ordinated response is high, and because of that desire, the ability is stronger. When everyone is starting to recover, the desire to co-ordinate is inevitably lessened, and as a result it will be more difficult. Luckily, this is probably a good thing. ...G20 members and their leaders have been very wise in the past 12 months. The G20 creation itself is a fantastic development. But let’s not require it always to have its members do the same thing at the same time.
\end{abstract}

Hopefully, resilience — bred of diversity — will prove to be a natural antidote to financial contagion of the most detrimental sort in the future, and the international seismographs finely enough tuned to detect the next financial earthquake.

104. See IOSCO Media Release, supra note 82.

105. Jim O’Neill, Op.-Ed., No Need For an Orderly Queue to Exit, Fin. Times (U.K.), Sept. 18, 2009, at 9, available at www.ft.com/cms/s/0/84ab191e-a3d3-11de9fed-00144feabdc0.html (last visited Feb. 23, 2011). 